\title{
The role of regulatory, market and governance risk for electricity access investment in sub-Saharan Africa
}

\author{
Giacomo Falchetta ${ }^{\mathrm{a}, \mathrm{b}, *}$, Anteneh G. Dagnachew ${ }^{\mathrm{c}, \mathrm{d}}$, Andries F. Hof ${ }^{\mathrm{c}, \mathrm{d}}$, David J. Milne ${ }^{\mathrm{d}}$ \\ a Fondazione Eni Enrico Mattei (FEEM), Corso Magenta 63, 20123 Milan, Italy \\ b Department of International Economics, Institutions and Development, Cattolica University, Largo Gemelli 1, 20123 Milan, Italy \\ c PBL - Netherlands Environmental Assessment Agency, Bezuidenhoutseweg 30, 2594 AV The Hague, Netherlands \\ d Copernicus Institute of Sustainable Development, Utrecht University, Heidelberglaan 2, 3584 CS Utrecht, Netherlands
}

\section{A R T I C L E I N F O}

\section{Article history:}

Received 14 October 2020

Revised 30 March 2021

Accepted 23 April 2021

Available online 6 May 2021

\section{Keywords:}

Electricity access

Regulatory quality

Governance

Discount rate

Sub-Saharan Africa

\begin{abstract}
A B S T R A C T
Achieving universal electricity access in sub-Saharan Africa - a milestone of SDG 7 - requires about \$30bn annually until 2030 on the top of baseline investment. The private sector plays a key role in supplying these investment flows, given the governmental budgetary constraints. Yet, private players face numerous sources of risk in their infrastructure investment decisions. This risk is usually factored in using a discount rate. To allow for a more realistic evaluation of the role of the investment environment in financing energy access, here we introduce the Electricity Access Governance Index (EAGI), a composite index of energy sector regulatory quality, energy sector governance, and market risk. The index is implemented through a discount rate conversion into a bottom-up integrated electricity planning model (IMAGE-TIMER) to evaluate the role of different sources of risk for electrification investment dynamics. Our results show that the adoption of decentralised systems for achieving universal energy access requires governance and institutional reform to lower discount rates faced by companies and households and mobilise private finance. Failure to reform investment environments will likely hamper the uptake of decentralised systems even in areas where they would be the technoeconomically least-cost electrification option, and thus likely leave many without electricity.
\end{abstract}

(c) 2021 International Energy Initiative. Published by Elsevier Inc. All rights reserved.

\section{Introduction}

Achieving the sustainable development goals requires a substantial ramp-up of baseline investment flows (McCollum et al., 2018). The financing gap is even larger in developing countries, where progress towards several SDG targets is still lagging behind (Ritchie \& Mispy, 2018). A relevant share of the estimated capital requirement is linked to the targets of universal energy access, as nearly 800 million people worldwide live without access to electricity and 2.6 billion lack access to clean cooking facilities (IEA \& IRENA, 2020). The bulk of the energy access deficit is concentrated in sub-Saharan Africa (SSA), a region emblematic of how an abundance of energy resources is not a sufficient condition for eliminating energy poverty.

Different sources have estimated the required additional annual power sector investments (including T\&D lines) in SSA at $\$ 30$ to $\$ 55$ billion (IEA, 2019; Lucas, Dagnachew, \& Hof, 2017) to provide electricity to the $\sim 575$ million without access in SSA. These large requirements derive from the capital-intensiveness of generation, transmission, and distribution infrastructure and its operation and maintenance costs. For

* Corresponding author at: Fondazione Eni Enrico Mattei (FEEM), Corso Magenta 63, 20123 Milan, Italy.

E-mail address: giacomo.falchetta@feem.it (G. Falchetta). instance, a renewable-based mini-grid to serve a local community can require an upfront investment of between $\$ 1250-5000 / \mathrm{kW}$ (Nerini et al., 2016); adding a $\mathrm{kW}$ of generation capacity to the national grid ranges between $\$ 1000-2500 / \mathrm{kW}$, depending on the technology implemented and the plant size (according to a survey by Enerdata (2016) for projects implemented in SSA over the last decade); mediumvoltage power transmission lines are estimated to cost an average $\$ 25,000 / \mathrm{km}$ (Karhammar et al., 2006). However, according to the available estimates, between 1990 and 2013 only \$31 billion has been invested in power generation in SSA (excluding South Africa), with $<16$ GW of generation capacity added (Eberhard, Gratwick, Morella, \& Antmann, 2016).

Several studies (Dagnachew, Hof, Roelfsema, \& van Vuuren, 2020; Simone \& Bazilian, 2019) have argued that a set of institutional, market-related, and financial barriers are the main factors responsible for the lack of energy supply infrastructure investment. As a result of these barriers, fundamental uncertainty remains over the sources of the required financing flows to the energy sector. This uncertainty is partly due to limited governmental investment in SSA, due to both low public revenues as share of GDP (World Bank, 2018) and high yielding national bonds (in most countries long-run bonds yield $>15 \%$, Investing.com, 2020). Lending large amounts of money at these rates would determine an escalation of public debt, which simply cannot be 
guaranteed. Given the limited opportunity of governments in providing finance, a crucial question is what the role of the private sector could be. The propensity of private players in the energy sector to seek business opportunities and thus meet the local demand for investment crucially depends on their perception of the local investment environment, which is influenced by - among others - regulatory and institutional quality and political stability (Iyer et al., 2015; Schmidt, 2019). Private players internalize a discount rate in their investment decisions (Schleich, Gassmann, Faure, \& Meissner, 2016) which is strongly affected by the degree of risk that they perceive in a given setting (Ryan \& Gallagher, 2006). In turn, this discount rate also mirrors the (implicit) discount rate of households when they decide upon their energyrelated investment (Reddy, 1996). By implicit discount rate we broadly mean "preferences, predictable (ir)rational behaviors and external barriers", quoting the energy-related definition provided in Schleich et al. (2016).

An example can clarify what this type of private (energy-related) discount rate refers to in the context of this paper. Suppose investor $X$ wants to invest in an energy project in country $Y$ and can lend money at an interest rate $i$ of $10 \%$. However - given the local governance structure and other political and market risks - the implicit discount rate $r$ of the investor at which the project is discounted throughout its lifetime is higher (say, 20\%). As a result, even though the expected rate of return (ERR) of the project is e.g. 12\% (greater than the lending interest rate), the investor decides not to invest because $i<E R R<r$. In principle, functioning capital markets should internalize all risk components in the lending interest rates and $i=r$ should hold. Yet, in the context of developing countries and development investments, the market interest rate could be of a country or source different from the project's location. Alternatively, even when capital is lent from the national capital market, in the case of private, small-scale energy access investments, the private discount rate is generally not equivalent to generic lending rates, as private players need to internalize the array of additional, project-specific risks in their project cost-benefit analysis, including insecurity of payment from the beneficiaries of their infrastructure. Historical lending rate data for specific private energy access investments could offer a picture of these private discount rates, but these data are simply not accessible in a systematic way.

In this context, this paper proposes a methodology to explicitly account for investment risk perceived by private players and it applies the approach to determine its impact on the optimal technological mix and investment requirements for universal electrification in SSA. We introduce a composite index of regulatory quality - the Electricity Access Governance Index (EAGI) - based on a large array of information on regulatory quality, governance, and stability. This index is used to estimate the energy access investment discount rate and is applied to the decentralised electricity access sector in the bottom-up electricity planning model TIMER (Dagnachew et al., 2017; Stehfest, van Vuuren, Bouwman, \& Kram, 2014; van Ruijven, Schers, \& van Vuuren, 2012) within the framework of the IMAGE integrated assessment model (Stehfest et al., 2014) for the SSA region. The EAGI embeds the role of the energy sector regulatory quality, as well as the general governance, investment environment, and political stability, and it determines the implicit energy investment discount rates.

The main objective of the paper is therefore to explore the impact of adjusting the baseline discount rate to country-specific sources of investment risk on the cost-efficient technology set-up (and primarily the trade-off between central grid expansion and decentralised solutions procurement) and investment requirements for achieving universal electricity access in SSA. The study aims at contributing to fill the literature gap found in recent model-based research assessing optimal electricity access supply options and investment requirements with a spatially-disaggregated approach (Morrissey, 2019). The latter research has focused largely on techno-economic dimensions (Dagnachew et al., 2017; Ellman, 2015; Mentis et al., 2017; Moner-Girona et al., 2019), without explicitly encapsulating the heterogeneity in the investment environment quality. The only notable exercises that have begun taking this direction are the recent work in Korkovelos et al. (2020), Spyrou, Hobbs, Bazilian, and Chattopadhyay (2019), Patankar, de Queiroz, DeCarolis, Bazilian, and Chattopadhyay (2019), who modelled the role of conflict in electrification and power systems planning.

The remainder of the paper is structured as follows. Background and literature review carries out a targeted literature review of the key dimensions assessed in the proposed methodology, namely private sector electricity access investment in SSA, the role of governance for private sector investment, and - more specifically - the significance of the discount rate as a measure of investment risk. The literature screening provides an understanding of the key drivers and consequences of risk for investors in the electricity sector in the context of developing countries. These factors are then embedded in the empirical analysis in Methodology, where we introduce the data and the methodology, which is divided into the EAGI index formulation and its implementation in the electrification model through its conversion into an implicit discount rate. Results and Discussion present and discuss the results, respectively. Conclusions concludes.

\section{Background and literature review}

Private investment in the power sector of Sub-Saharan Africa

Between 1990 and 2013, only 16 GW of generation capacity were added throughout SSA (Eberhard et al., 2016). These power plants have been predominantly procured by independent power producers (IPPs) (Eberhard \& Gratwick, 2013) and financed by governments and multilateral development banks. While over the last ten years Chinese funding (enabled mostly through Chinese state-run banks lending to Chinese state-run companies; see Powanga and Giner-Reichl (2019)) has become the first source of investment after direct governmental investment in the power sector of SSA (Eberhard et al., 2016), in the same period there has been only a moderate upward trend in IPP investment flows.

One of the most notable attempts to collect information and shed light on investment flows is Eberhard, Gratwick, Morella, and Antmann (2017). The authors show that while IPPs (Independent Power Producer) have invested growing amounts of capital in energy project in SSA ( $>0.7$ billion USD in 2014), the bulk of the recently added new generation capacity procured by private or foreign players has been concentrated in only 15 of the nearly 50 countries of SSA, notably in Nigeria (about $1.5 \mathrm{GW}$ ), Kenya (1.1 GW), Ghana (about $1 \mathrm{GW}$ ), and Cote d'Ivoire ( $900 \mathrm{MW}$ ). These statistics offer a glance of the ongoing investment trends, but the lack of a public and systematic database of private sector investment flows into the energy sector of countries in SSA hinders a clear and up-to-date understanding of the situation and its evolution. In turn, this lack of information is reflected in the paucity of academic literature analyzing energy-related investments flows in SSA to understand their drivers and impacts.

Another crucial factor to consider is the substantial evidence of an important role of peering dynamics in investment decisions (Zaighum \& Karim, 2019), where companies follow companies and systematically target their infrastructure projects towards certain countries and regions where there is already a vivid investment environment. This can be described as a way to reap the positive externality of the information collection costs previously incurred by the company itself or by its competitors (Chen \& Ma, 2017).

\section{The role of governance for private investment}

In the context of the power sector of SSA, investment can be represented as a function of uncertainty and reward, with the financial risks and barriers to electricity infrastructure emerging at different scales (Gregory and Sovacool 2019). Namely, through micro factors - which include factors at the project or infrastructure level -, meso factors, 
encompassing national aspects such as regulation or assets, and macro factors, which are linked to global dynamics such as exchange or interest rates. Meso-factors are the crucial ones for the scope of the analysis we present in this paper, because the quality of governance and the political stability directly affect the amount and nature of investment in a country through their impact on the degree of uncertainty for business and thus the final costs they incur in Eifert, Gelb, and Ramachandran (2005), Emery (2003), Ramachandran, Gelb, and Shah (2009).

A broad stream of literature has engaged with the analysis of the role of governance for attracting private-sector investment. Eberhard et al. (2017) discussed how planning, competitive procurement and contracting, risk mitigation, credit enhancement, power markets, and regulation are the crucial explanatory factors for the level of private investment. Sergi et al. (2018) showed that national institutions and governance have a considerable impact on the development of different electricity access technologies. They compared the example of Kenya, where power sector unbundling and privatization efforts have mostly attracted private investment in on-grid projects, with the case of Tanzania, where less tight regulations for off-grid power producers are in place, including clearer regulatory framework for imposing costreflective tariffs to households connected to mini-grids. They argue that the latter regulatory environment creates a more supportive environment for niche innovation, which is reflected in the thriving mini-grid sector in Tanzania, which not by chance counts the most mini-grid customers (ESMAP, 2019).

Empirical evidence from pay-as-you-go (PAYG) solar home system contracts subscribed in Benin shows that PAYG service providers target credit-worthy consumers with the implicit objective of reducing their investment risk. The authors argue that these results cast doubts as to whether PAYG (and in general privately-provided decentralised energy access solutions) bridges the "last mile" electrification gap. These doubts are also fed by the fact that nearly all PAYG customers in the country are within short physical distance from the grid but choose the PAYG services because of service reliability and affordability.

Afidegnon (2019) investigated the success factors for power project development businesses in SSA. He collected data from semi-structured interviews to explore the strategies used by executives of four companies in SSA who successfully developed power projects within the last 5 years. His results show that the interviewed CEOs attached great significance to the development a deep knowledge of the target market and aligning the stakeholders' expectations using a combination of local partnership and international consultants. Moreover, CEOs attributed a foremost role to ensuring the commercial viability of the project through bankable project agreements and the implementation of appropriate risk management and credit enhancement tools.

The evidence and arguments collected in this literature screening provides the basis for the data collection for the construction of the EAGI discussed in Methodology.

\section{The discount rate as a measure of investment risk}

To factor qualitatively perceived risks - such as those stemming from a low regulatory quality - into structured models of investment decisions, these risks have to be translated to a quantitative measure. A seminal contribution by Hirshleifer (1961) introduced a market theory of risk, proposing to expand the theory of present value maximisation by modifying the discount rate to account for the risk component of investments. According to this theory, investments are discounted by a baseline risk-free rate (Lintner, 1969) that accounts for the pure value of time - i.e. the trade-off between consumption in the present and the future -, on top of which a risk premium is added. The latter takes into consideration the additional sources of risk that the investor perceives in the context of the project under examination, but which not always are encapsulated in the market interest rate.

Yet, there is no standard methodology to translate a qualitatively perceived risk - such as political instability, corruption, low regulatory quality, currency inflation and consumer debt repayment issues - into a risk-adjusted discount rate. This is because of the large variety of potential sources of risk, which are often project-specific. Also for the specific case of private infrastructure investment, there are no set guidelines for determining the discount rate (Short, Packey, \& Holt, 1995). A 2015 survey on valuation methodology in Africa (PWC, 2015) inquired into how the private sector incorporates risk in the valuation of an investment. This analysis showed that most respondents incorporate risk associated with infrastructure projects in Africa in the discount rate. For capital-intensive projects, it is often the case that multi-national or foreign companies have access to capital in markets with significantly lower interest rates than in most countries of SSA, and yet they must encapsulate the risk of investing in a foreign country into their investment decisions. A survey carried out in 2018 (Thornton, 2018) among utility-scale renewable energy developers in SSA in Kenya, Nigeria, and South Africa inquired on the discount rate used in potential ground-mount solar and onshore wind market projects, finding values in the range of $14.75-18 \%$.

Yet, when considering smaller-scale energy investments carried out by private actors, the role of additional sources of risk becomes crucial and is likely not encapsulated in the capital market. Private discount rates include both sector-specific risks and the implicit discount rates of households when they decide upon their energy-related investment ((Train, 1985), i.e. the payback time they are willing to accept). Empirical evidence has shown that the applied discount rates for fuel choices are much higher for low income households (up to 80\%) that for affluent households (down to 10\%) (Daioglou, van Ruijven, \& van Vuuren, 2012). Seminal contributions specific to the role of the discount rate in energy access and energy carrier choices decisions include the work of Reddy (1996), who modelled the relationship between household income and energy carrier choices, showing that households shift from one energy carrier to another if their income increases and that the consumer discount rates decrease exponentially with household income.

\section{Methodology}

Building on the evidence found in the literature on the key sources of risk affecting private discount rate in energy access investment, here we enrich a conventional electrification analysis with regulatory, governance, and political factors (Fig. 1). Factors that are strong predictors of electricity access (Bonan, Pareglio, \& Tavoni, 2017; Khennas, 2012) and private sector investment (Asongu \& Nwachukwu, 2015; Drogendijk \& Blomkvist, 2013; Hornberger, Battat, \& Kusek, 2011; Ndikumana \& Verick, 2008) are summarized into an Electricity Access Governance Index (EAGI; The Electricity Access Governance Index (EAGI): Input data and indicator aggregation) which is then used to simulate the role of regulatory quality on private investment decisions via the discount rate (Implementing the effect of EAGI on the discount rate). For selected countries, an in-depth country exercise is carried out to characterize sub-country heterogeneity in the propensity of private players to invest in different regions of a country. These are detailed in Introducing within-country heterogeneity in selected case study countries. As detailed in The IMAGE-TIMER model, The EAGI index is then fed into the TIMER simulation model, which yields results over optimal technological mix and investment requirements in every grid cell. Input data and scenarios considered describe the data and scenarios considered in the current analysis, while The impact of EAGI-adjusted discount rates on the electrification set-up in the TIMER model highlights the underlying mechanisms through which changes in the discount rate affect the optimal electrification planning.

The Electricity Access Governance Index (EAGI): input data and indicator aggregation

Based on literature screening, we consider socio-economic factors that are correlated to the levels of electricity access in SSA and 


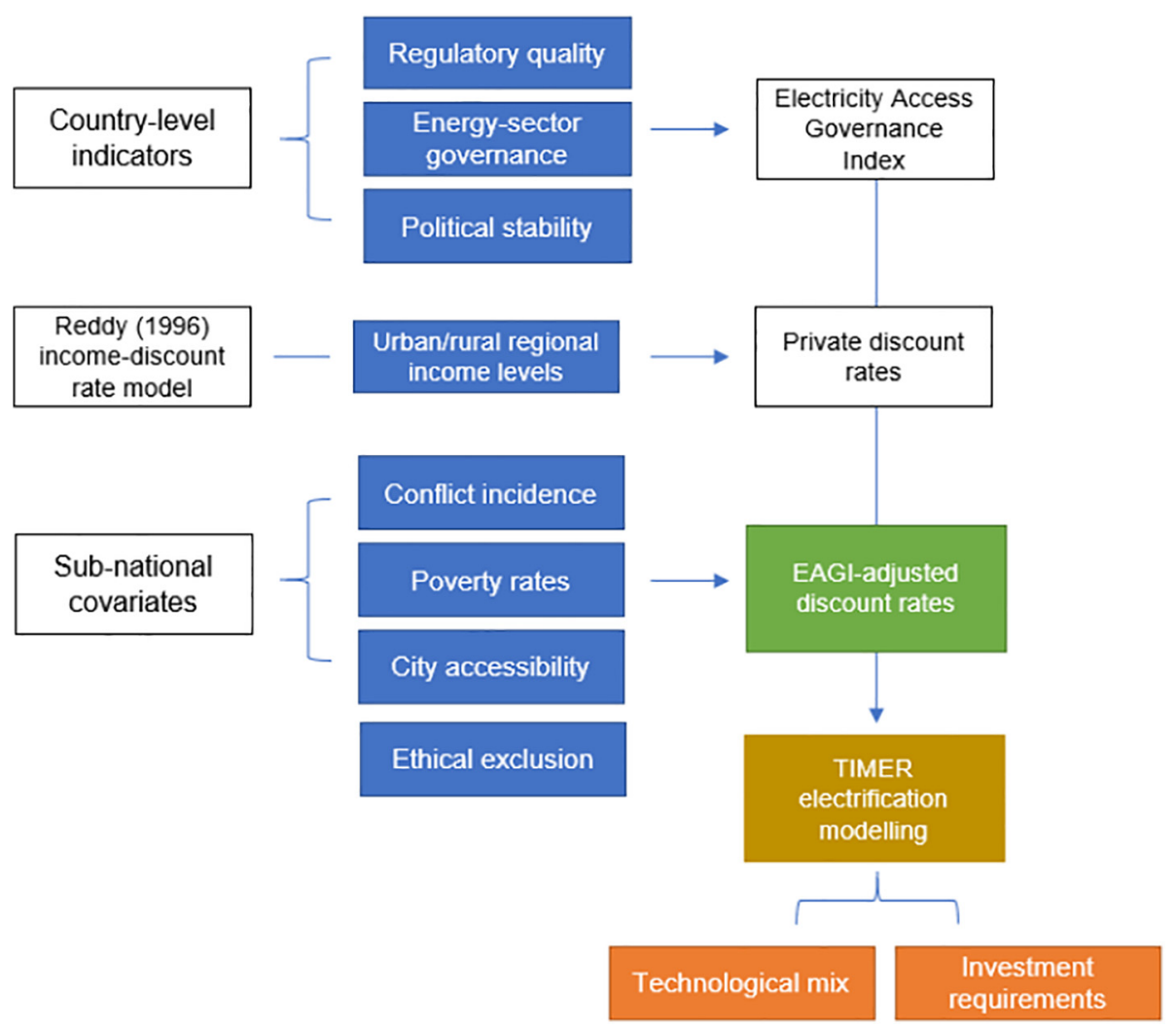

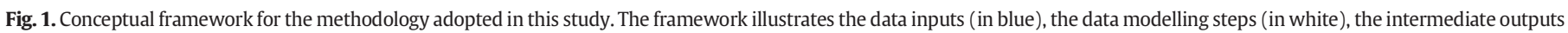
(in green), the electrification analysis (in yellow), and the final results (in orange).

regulatory and governance-related factors that are specific to private sector investment decision making, with a particular focus on renewable energy and off-grid technologies. Indicators are chosen based on data availability and quality; only indicators with recent (post 2010) data available are considered suitable due to the rapidly developing nature of the electricity sector in SSA. Table 1 summarizes the input data sources used for the EAGI formulation. These are explored in greater detail with descriptive statistics and graphs in the Supplementary Materials.

The indicators are aggregated using a principal component analysis (PCA). PCA is a multivariate statistical method that is used in development research to reduce the number of variables (dimensions) in a dataset and construct composite indices. This technique was first used by Ram (1982)) in the construction of a 'physical quality of life index' and has been used in various fields of development and environmental research since (e.g. Lai (2003), Cahill and Sanchez (2001), Khatun (2009), Orea, Growitsch, and Jamasb (2015)). The different variables are weighted according to the amount of their variance explained by the first principal component (Booysen, 2002). PCA is only applicable when the variables used are correlated with each other. Rather than a simple mean calculation, PCA gives a more representative score by analyzing correlations between different variables (indicators in this case). The decision to use a PCA in the context of this study is justified by the necessity to come up with a univariate measure summarizing different indicators (in our data 7 variables for 46 observations, an acceptable ratio to use PCA according to Bandalos and Boehm-Kaufman (2009)) that can later be translated into a private discount rate proxy. Supervised dimension reductions techniques, which are shown to be superior in regression performance (Orea et al., 2015), are not applicable to our case, as our dimension reduction exercise is not finalized at carrying out regression analysis, and we thus do not have a dependent variable of reference. The dimension reduction step is thus only finalized at generating a composite index (the EAGI).

Algebraically, a PCA is carried out with the following routine: first, the $d \times d$ covariance matrix of the selected variables for the EAGI is calculated as in Eq. (1):

$\operatorname{cov}(X, Y)=\frac{1}{n-1} \sum_{i=1}^{n}\left(X_{i}-\bar{x}\right)\left(Y_{i}-\bar{y}\right)$

Table 1

Input data sources for the country-level EAGI formulation.

\begin{tabular}{|c|c|c|c|c|}
\hline Data & Variable(s) considered & Category & Temporal and spatial resolution & Source \\
\hline $\begin{array}{l}\text { Regulatory Indicators for Sustainable Energy } \\
\text { (RISE) }\end{array}$ & $\begin{array}{l}\text { Multiple KPIs } \\
\text { (see SI) }\end{array}$ & $\begin{array}{l}\text { Energy sector } \\
\text { governance }\end{array}$ & 1 year, country-level & (RISE, 2019) \\
\hline Transparency International - CPI & Corruption Perceptions Index (CPI) & Politics & 1 year, country-level & (Transparency International, 2019) \\
\hline The Worldwide Governance Indicators (WGI) & Government Effectiveness & Politics & 1 year, country-level & (Kaufmann, Kraay, \& Mastruzzi, 2011) \\
\hline Ibrahim Index of African Governance & Sustainable Economic Opportunity & Market & 1 year, country-level & (Ibrahim, 2013) \\
\hline Euler Hermes - Country Risk Reports & Country short and medium term risk & Market & 1 year, country-level & (Hermes, 2017) \\
\hline
\end{tabular}


where $n$ is the number of observations in the data (i.e. in our case the number of countries), $X_{i}$ and $Y_{i}$ are each couplet of variables at the $i^{\text {th }}$ observation, and $\bar{x}$ and $\bar{x}$ are the mean values of each couplet of variables, respectively.

Then, eigenvalues $\lambda$ s (roots of the characteristic equation $\operatorname{det}(A-$ $\lambda I)=0$, where $A$ is the original data matrix and $I$ is an identity matrix) and eigenvectors from the covariance matrix are calculated and sorted by decreasing eigenvalues. Finally, only the k eigenvectors with the largest eigenvalues to form a $d \times k$ dimensional matrix $W$ are retained, i.e. those that bear the most information about the distribution of the data. To conclude, the matrix $W$ is used to transform the initial observation onto the new subspace via the equation $y=W^{\prime} \times x$, where $W^{\prime}$ is the transpose of the matrix $W$. The results of the EAGI calculation are included in the Supplementary Materials. We select the first principal component, which explains $78 \%$ of the total variance, a more than satisfactory fraction in the social sciences domain (Hair, 2009).

\section{Implementing the effect of EAGI on the discount rate}

Poor governance increases both the perceived and the actual risk of investment in a given project, which can have negative consequences on the profitability of an investment (Jensen, 2003). In Eq. (2), the annuity factor $A F$ reflects the present value of future income from a given investment after $i$ periods. Here, the discount rate $r$ reflects the risk of an investment: the higher the discount rate, the riskier the project, and the lower the $A F$ (which defines the expected return):

$\mathrm{AF}=\frac{1-(1+\mathrm{r})^{-\mathrm{i}}}{\mathrm{r}}$
Here we aim at describing a similar dynamic in the electrification process - with a particular focus on the decision of private actors to perform capital-intensive investment in electricity access technologies. We have fully integrated the modelling approach for the discount rate in the context of electrification and energy carrier choices introduced in Reddy (1996), Train (1985) into the TIMER model (Dagnachew et al., 2017; Dagnachew, Lucas, Hof, \& van Vuuren, 2018; Daioglou et al., 2012). In doing so, we define boundary discount rate values (Fig. 2A).

These values are based on the highest and lowest quintiles of household income, for urban and rural areas separately. In the TIMER model, SSA is divided in to four sub-regions: Western \& central Africa, Eastern Africa, the Republic of South Africa, and the rest of southern Africa. The boundary discount rates are identified for each of these sub-regions. These are derived with the following equation:

$\ln (C D R)=6.3822-0.0082 I$

where $\ln (C D R)$ is the natural logarithm of the private discount rate, and $I$ is income (in the original specification of Reddy (1996) expressed in Indian rupees/capita/month as of 1996). Thus, $C D R^{\max }$ and $C D R^{\min }$ are derived as:

$C D R^{\min / \max }=\frac{e^{\left(6.3822-\frac{0.00821 q_{k}}{m}\right)}}{100}$

where $I^{q}$ are the first and fifth income quintiles of households in each region of SSA, $k=29.756$ is a conversion factor from 2011 US dollars
A Per-capita regional
GDP quintiles

\begin{tabular}{|l|l|l|l|}
\hline Region & Type & 1st quntile & Sth quntile \\
\hline $\begin{array}{l}\text { East Af. } \\
\text { West At. }\end{array}$ & Urban & $\ldots$ & $\cdots$ \\
Southn. Af. & & -- & $\cdots$ \\
Rep. S. Aft. & & & \\
\hline
\end{tabular}

B

Boundary regional discount rates

\begin{tabular}{|l|l|l|l|}
\hline Region & Type & Min DR & Max DR \\
\hline East Af. & Urban & $\ldots$ & - \\
West Af. & Rural & $\cdots$ & - \\
Southn. Af. & & & \\
Rep. S. Afr. & & & \\
\hline
\end{tabular}

Country-specific EAGI-

C adjusted discount rates

\begin{tabular}{|l|l|l|}
\hline Country & Type & EAGI-DR \\
\hline AGO & Urban & $\ldots$ \\
BO & Rural & $\ldots$ \\
BWA & & \\
$-\cdots$ & & \\
\hline
\end{tabular}

Boundary regional discount rates

$\Rightarrow$\begin{tabular}{|c|l|l|l|l|}
\hline $\begin{array}{c}\text { Reddy (1996) } \\
\text { model }\end{array}$ & Region & Type & Min DR & Max DR \\
\hline \begin{tabular}{ll|l} 
East Af. \\
West Af. \\
Southn. Af. \\
Rep. S. Afr.
\end{tabular} & $\begin{array}{l}\text { Urban } \\
\text { Rural }\end{array}$ & $\ldots$ & $\ldots$ \\
\hline
\end{tabular}

\section{Country-specific EAGI-} adjusted discount rates

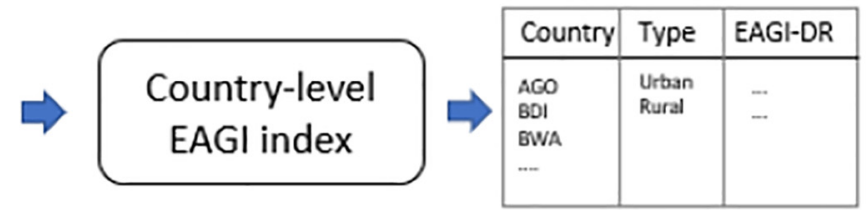

Spatially-explicit EAGIadjusted discount rates
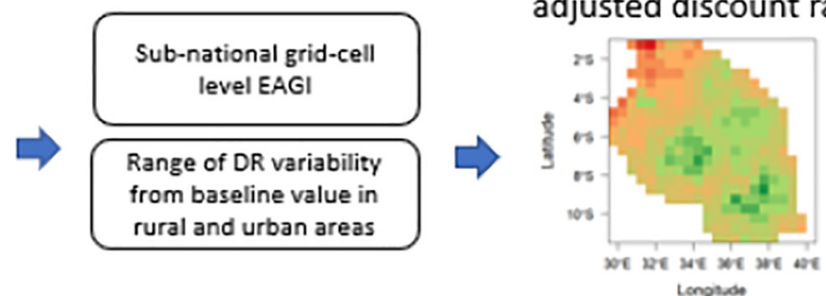

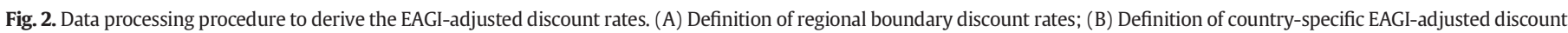
rates; (C) Downscaling of the country-specific EAGI-adjusted discount rates to the grid-cell level EAGI-adjusted discount rates for the case-study countries. 
(which are the unit of reference for the per-capita average monthly GDP of SSA used in this study) into the original currency. ${ }^{1}$ The reason for choosing the coefficients as estimated by Reddy is that the GDP per capita levels used in that study are similar to those in rural subSaharan Africa currently (in PPP terms; (World Bank, 2018; Davis, Di Giuseppe, \& Zezza, 2017)). Limitations provides a discussion of the limitations of applying the coefficients estimated by Reddy (1996) on current sub-Saharan Africa.

Given the lack of availability of granular household income data, we refer to per-capita GDP quintiles. Once boundary discount rate values for each region are derived, the EAGI is linearly normalized (Fig. 2B) between this interval (with higher values of the EAGI corresponding to lower values of the discount rate) via the following formula:

$D R_{i}^{u r}=\left(b_{r}^{u r}-a_{r}^{u r}\right) \frac{x_{i}-\min x}{\max x-\min x}+a_{r}^{u r}$

where $a$ and $b$ are the lower and upper discount boundaries for the region to which country $i$ belongs, respectively, $\mathrm{x}$ is the corresponding EAGI, and the ur superscript identifies urban and rural discount rates, respectively. The input numbers for each of the calculation steps are reported in the Supplementary Materials. The result of the modelling yields a set of country and urban-rural heterogeneous discount rates which are linked both to the country-specific regulatory risk and to the region of belonging. These are reported and discussed in EAGI and implicit discount rates.

The calculated private discount rates differ from the discount rate of the central energy system model that is applied e.g. to investment in the central grid, which in IMAGE-TIMER is set at 10\%, the same value considered by the World Bank in infrastructure investments in developing countries (Pueyo, Bawakyillenuo, \& Osiolo, 2016). The latter expresses the cost premium at which society is willing to defer today's benefits in the future, or, equivalently, to accept tomorrow's cost in the present. On the other hand, the EAGI-adjusted discount rates refer to the private discount rates in the energy sector of SSA, namely the rate of return that private companies and households are seeking in order to make an investment in the present. Poverty, poor regulatory quality, political instability, and market risk all contribute to increasing the risk of making an investment in the present with returns in the future, and therefore imply the necessity of higher expected return in order to accept that risk.

\section{Introducing within-country heterogeneity in selected case study countries}

The methodology introduced mostly focused on a characterisation of the between-country differences in regulatory quality and the relative impact on electricity access investment. This is because generally, the investment environment is determined by national regulation, institutions, and governance that are effective throughout a sovereign country. Yet, it is often the case - and not only in developing countries - that even within a country, there is substantial heterogeneity in the capacity to attract investment. This is a consequence of regional differences in risks. In an attempt to characterize this sub-national differentiation in the context of electricity access investment in SSA, we select four country-studies, namely Nigeria, Tanzania, Uganda, and Malawi, which together host >160 million people without access to electricity (IEA \& IRENA, 2020) and where highly unequal distribution of electricity access is observed (Falchetta \& Pachauri, 2020). Given the continental scale of this paper and of the energy investment model considered, we do not implement the sub-national inputs because a geospatial electrification model operated at a higher-resolution (generally $<1 \mathrm{~km}^{2}$ ) would

\footnotetext{
${ }^{1}$ Based on https://www.historicalstatistics.org/Currencyconverter.html.
}

be required to appreciate the characterisation of the sub-national heterogeneity in the EAGI discount rate.

We retrieve a set of spatially-explicit data (detailed in Table 2) which - consistently with the screened literature presented in Background and literature review - are deemed strong drivers of the perception of investment risk by private players. These include the PRIO Conflict Site georeferenced dataset on the historical incidence and size of armed conflict in 1989-2008 (Dittrich Hallberg, 2012); the WorldPop poverty maps derived from cell phone and satellite data coupling to household surveys, which report the proportion of people per grid cell living in poverty (Tatem et al., 2013); a measure of accessibility derived from Weiss et al. (2018) for estimating the travel time to the nearest city from any given settlement; and a dataset of excluded ethnic groups in each grid cell (Vogt et al., 2015), which has been shown to be strongly correlated with infrastructure investment in Africa (De Luca, Hodler, Raschky, \& Valsecchi, 2018). The variables are plotted in Fig. 3 for Uganda, one of the four case-study countries selected. Altogether, these spatially-disaggregated factors are deemed effective predictors for the propensity of a private actor to select a given site for infrastructure investment within a country.

Based on a PCA on the spatially-explicit datasets, we operate an adjustment (Fig. 2C) to the baseline country discount rate estimated via the national EAGI to describe within country-heterogeneity in the potential perceived risk by private investors, and we analyze the results of the electrification analysis with and without the adjustment to understand its implications. The adjustment is within a $\pm 25 \%$ range for rural areas and $\mathrm{a} \pm 15 \%$ range for urban areas, and it follows a gridcell level PCA and normalisation approach in the same fashion as described in Implementing the effect of EAGI on the discount rate. We distinguish between urban and rural areas based on the GHS-SMOD classification. Refer to the Supplementary Materials for a detailed account of the calculation of the sub-national EAGI-adjusted discount rate.

\section{The IMAGE-TIMER model}

The Targets IMage Energy Regional (TIMER) model is an energy model that forms part of the IMAGE 3.0 framework, developed at PBL Netherlands Environmental Assessment Agency (Stehfest et al., 2014). IMAGE 3.0 is an integrated modelling framework that represents interactions between human and natural systems to investigate sustainability issues such as climate change, biodiversity and human well-being. IMAGE is used to analyze large-scale and long-term interactions between human development and the natural environment; hence, it is a data-intensive model. IMAGE has 26 world regions that enables it to capture spatial and multi-scale differences. TIMER is a simulation model that explores long-term trends in demand and supply of different energy carriers, energy access and the possible transition pathways towards low-carbon energy systems. Within the context of IMAGE, TIMER also describes energy-related greenhouse gas emissions (introduced in De Vries, Van Vuuren, Den Elzen, \& Janssen, 2002).

TIMER model is used in several studies in the past, for instance, to explore residential energy use in developing countries (Van Ruijven et al., 2008), to assess future trends in rural electrification and the associated investment needs in developing countries (van Ruijven et al., 2012), and to analyze possible future developments of residential energy use in developing regions (Daioglou et al., 2012). Research carried out by Dagnachew et al. $(2017,2018)$ used an extended version of this model to investigate the cost and benefits of various pathways towards universal electricity access in SSA, specifically including several off-grid electrification options. The latter studies were carried out on a $0.5^{\circ} \times 0.5^{\circ}$ gridcell level, allowing results to be aggregated into countries. The SSA Electrification model that forms part of TIMER model is the main instrument of this study. The electrification model incorporates a customdesigned decision tree (see Fig. 4) to determine the least-cost electrification option based on the proximity of the grid-cell to an existing 
Table 2

Input data sources for the within-country case studies.

\begin{tabular}{|c|c|c|c|c|}
\hline Data & Measured variable(s) & Category & Temporal and spatial resolution & Source \\
\hline PRIO Conflict Site & $\begin{array}{l}\text { Count of armed conflict events; radius } \\
\text { of affected area }\end{array}$ & Political stability & $\begin{array}{l}\text { Exact date in 1989-2008 range; } \\
50 \mathrm{~km} \text { buffer }\end{array}$ & (Dittrich Hallberg, 2012) \\
\hline WorldPop poverty maps & $\begin{array}{l}\% \text { of people living below poverty } \\
\text { threshold }\end{array}$ & $\begin{array}{l}\text { Socio-economic } \\
\text { indicators }\end{array}$ & 1 year; 1 km & $\begin{array}{l}\text { (Tatem, Gething, Bhatt, Weiss, \& } \\
\text { Pezzulo, 2013) }\end{array}$ \\
\hline $\begin{array}{l}\text { Travel time to the nearest } 250,000+ \\
\text { inhabitants city }\end{array}$ & Minutes of travel time & $\begin{array}{l}\text { Centrality and } \\
\text { accessibility }\end{array}$ & 1 year; 1 km & $\begin{array}{l}\text { Major cities data: ESRI; algorithm: } \\
\text { Weiss et al. (2018) }\end{array}$ \\
\hline GeoEPR & Excluded ethnic groups & Political stability & $0.5^{\circ}$ & (Vogt et al., 2015) \\
\hline GHS-SMOD & Urban/rural prevalence & $\begin{array}{l}\text { Centrality and } \\
\text { accessibility }\end{array}$ & 5 years; $250 \mathrm{~m}$ & (Pesaresi \& Freire, 2016) \\
\hline
\end{tabular}

power line, the household electricity demand, the population density of the grid-cell, and the cost and availability of local energy resources.

The model provides the least-cost electrification option for each grid-cell in SSA. The input data (population, electricity consumption, grid infrastructure in place, solar/wind/hydro potential, etc.), along with the underlying optimization formulas and full list of parameters used in the model are given in the SI of Dagnachew et al. (2017). The applied model considers different technology options for mini-grid and standalone systems. Standalone systems are isolated systems that can be adopted by individual households and provide up to $250 \mathrm{Wp}$. These systems do not require transmission and distribution network. Mini-grid systems provide power to a community or small town and comprise low-voltage distribution network. They can be designed to be connected to the national grid with no limit on peak power. Central grid expansion requires high investments in extending the transmission and distribution network and scaling up of generation capacity. The specific characteristics of each technology used in the model, the grid expansion options, and the cost data used can be found in Dagnachew et al. (2017).

For the purpose of this study, the model is updated with gridded nighttime light data for electricity access and consumption as developed by Falchetta, Pachauri, Parkinson, and Byers (2019). In addition, EAGIadjusted discount rates are used instead of the standard discount rate used in the model in the previous studies. The model determines the least-cost technology for each grid cell, based on the consumption levels reached in 2030, when universal access in SSA is set to be achieved. The model results visualize and quantify what the cost-optimal technology is for each grid-cell, identifying grid-cells that are viable for off-grid systems, which can be procured by the private sector.

The impact of EAGI-adjusted discount rates on the electrification set-up in the TIMER model

A brief theoretical discussion of how EAGI-adjusted discount rates affect energy-related investment decision is useful for understanding the results of the analysis. In general, the TIMER model selects - at each grid cell - the technology with the lowest levelized cost of electricity (LCOE). The LCOE of technology $i$ is defined as:

$$
\begin{gathered}
L C O E_{k}=\frac{\frac{1}{(1+i)^{t}}+\sum_{t=1}^{N} \frac{O M_{k t}+F_{k t}}{(1+r)^{t}}}{N} \\
\sum_{t=1} \frac{E_{k t}}{(1+r)^{t}}
\end{gathered}
$$

where, for each technology $k$ at each time $t, I_{k t}$ represents the upfront capital invested (the CAPEX) which is lent at a market interest rate $i$, $O M_{k t}$ are operation and maintenance costs and $F_{k t}$ are fuel costs

\section{Nigeria, gridded EAGI input data}
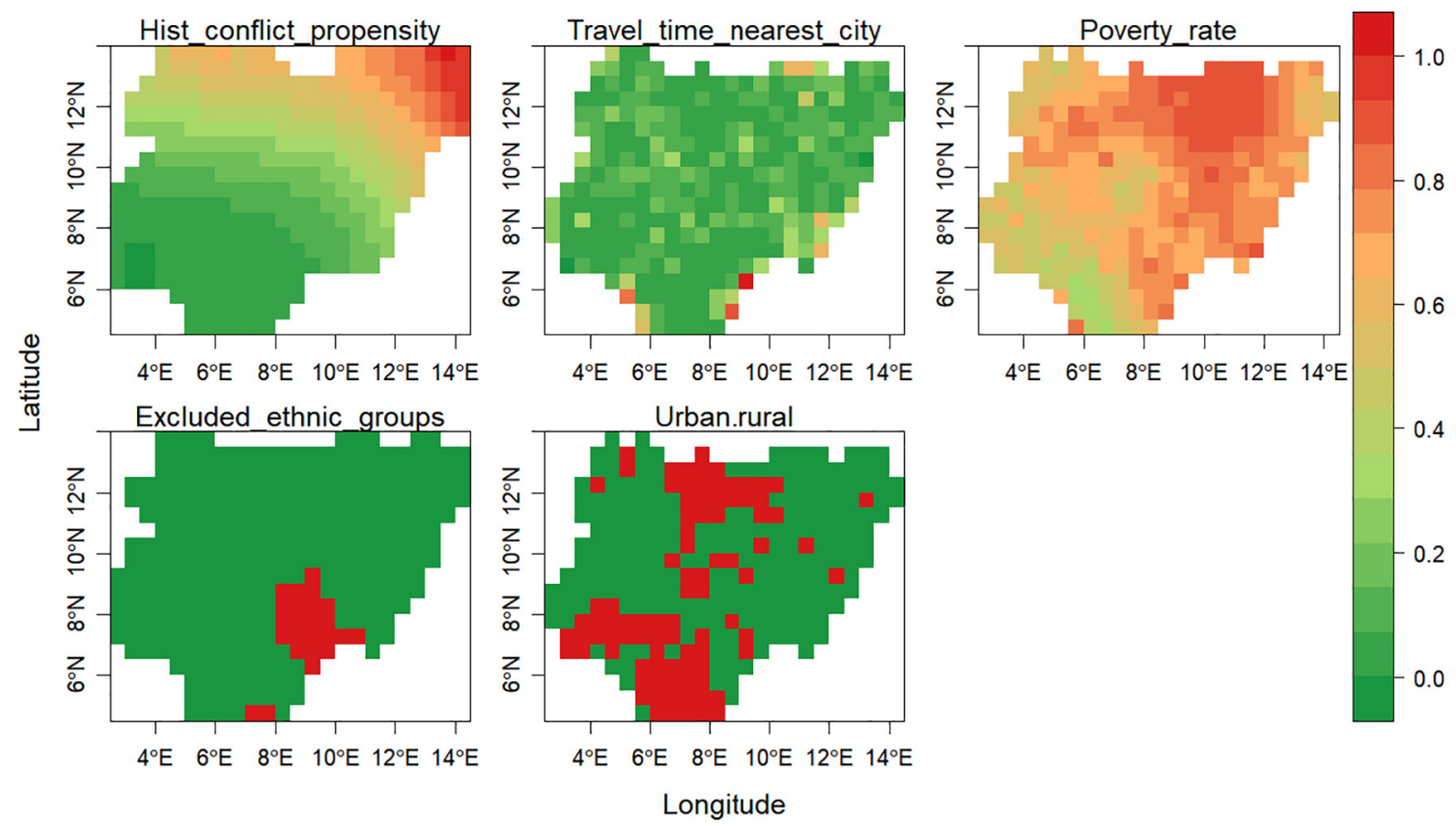

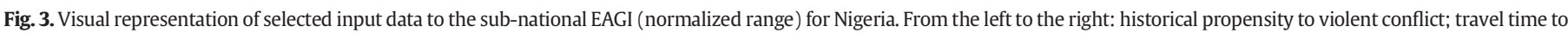
the nearest 50,000 inhabitants city; fraction of population living in poverty; density of excluded ethnic groups; prevalent settlement type $(1=$ urban, $0=$ rural $)$. 
Decision tree to determine the lowest-cost electrification system

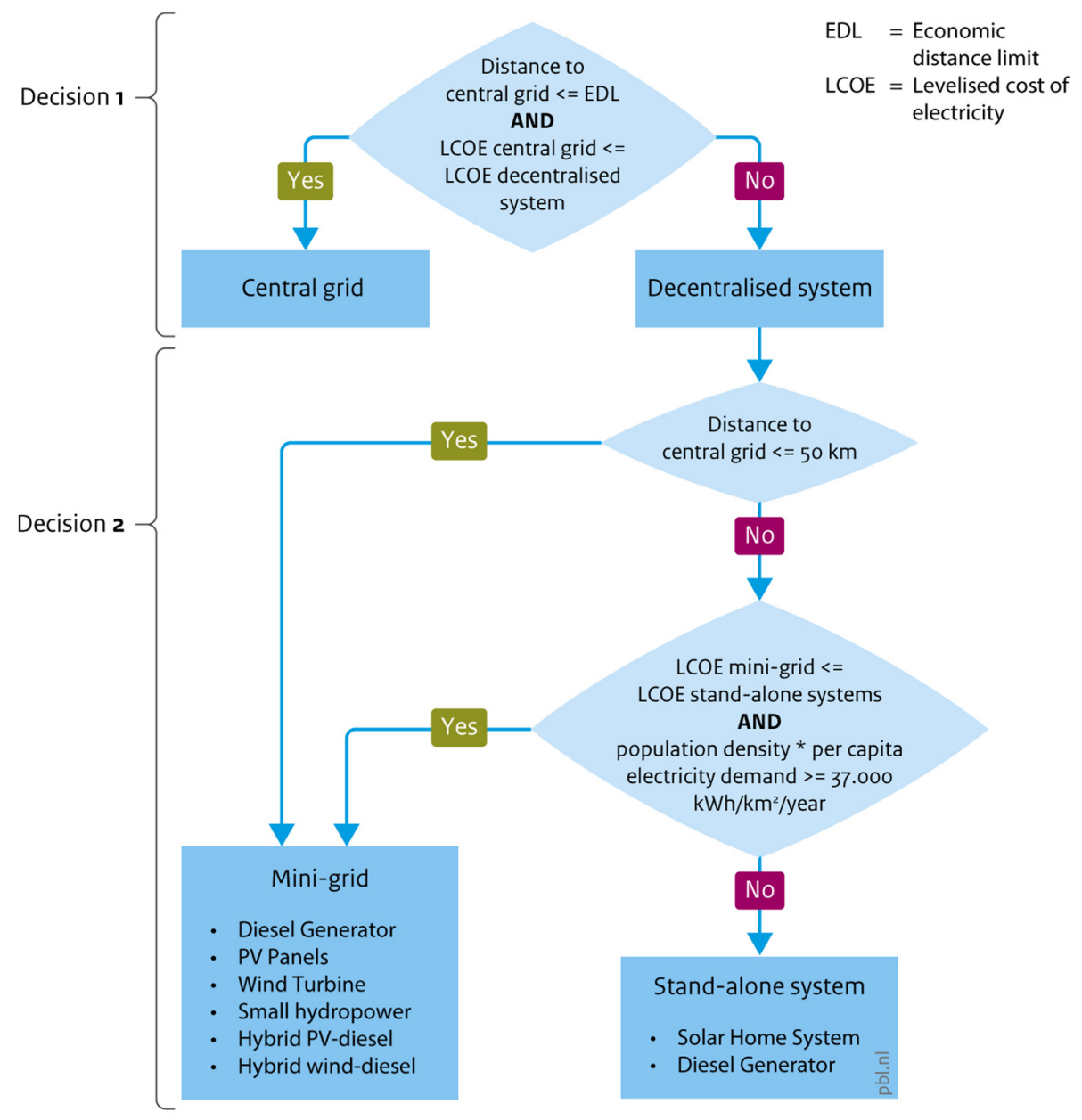

Source: PBL

Fig. 4. Decision tree for the IMAGE-TIMER Sub-Saharan Electrification model.

(together, the OPEX or running costs), $E_{k t}$ is the electricity generated, $r$ is the discount rate (which in a risky investment context is usually $>i$, as $i$ might be obtained from less risky capital markets or from development banks), and $N$ is the lifetime of the technology in question.

What happens if a consideration of the EAGI implies a ceteris paribus higher discount rate $r$ ? The upfront component (CAPEX) does not depend on the discount rate in the LCOE calculation, while the OPEX does. Therefore, given two technologies $i$ and $j$ with (discounted) $\frac{\text { CAPEX }_{i}}{{ }_{\text {OPEX }}}>\frac{\text { CAPEX }_{j}}{\mathrm{OPEX}_{j}}$, a higher discount rate implies that the net present value (NPV) of the OPEX becomes lower and therefore both ratios increase, albeit the ratio of technology $\mathrm{j}$ diminishes at a faster rate. This discrepancy is in turn reflected in the LCOE of each technology: while the upfront component I remains fixed, the OPEX varies with the discount rate.

Given the prevalent cost-structure of central grid expansion (generally per-household grid connections are characterised by lower perconnection CAPEX and higher OPEX) relative to decentralised solutions (higher per-connection CAPEX, lower OPEX), a growing discount rate $r$ (i.e. a riskier investment context) tends to imply an increasing share of national grid-based electrification. This is the result of the fact that a higher discount rate benefits the deployment of investment at $t=0$ in technologies that have higher running costs throughout their lifetime (fuel and operation and maintenance), since the present value of such future costs becomes comparatively smaller. Thus, in a number of settlements, higher discount rates imply decreasing investment in decentralised systems (which, albeit with different cost structures e.g. between standalone PV and diesel gen-sets, tend to have a higher perconnection CAPEX-to-OPEX ratio relative to the national grid) because lending capital today in these situations is relatively more expensive. In addition, households are often credit constrained because their income is usually lower than the CAPEX of e.g. a diesel generator. Irregular income flows and the lack of collateral are responsible the high lending rates and, as a result, even purchasing a generator in instalments becomes unfeasible (Blimpo, Postepska, \& Xu, 2020).

\section{Input data and scenarios considered}

To explore the pathways for universal access in 2030, we use demographic and economic projections from the Shared Socioeconomic Pathway (SSP) (Riahi et al., 2017). SSPs are a set of alternative futures of societal development used by climate change research community to investigate climate impacts as well as options for mitigation and adaptation. For the purpose of this study, we choose SSP2 scenario since it represents moderate population growth and economic growth, along with acceptance for all energy conversion technologies that do not shift considerably from historical patterns. Historical household electricity demand is calibrated based on Falchetta et al. (2019). The approach calibrates real historical electricity consumption information based on night-time satellite imagery and other spatially-explicit data. 
Table 3

Table of the scenarios considered in the electrification analysis.

\begin{tabular}{|c|c|c|}
\hline Scenario & Discount rates & EAGI \\
\hline Baseline & $\begin{array}{l}\text { TIMER baseline } \\
\text { (regional) }\end{array}$ & - \\
\hline Baseline-EAGI & EAGI-adjusted & Baseline \\
\hline $\begin{array}{l}\text { Moderate } \\
\text { improvement in } \\
\text { EAGI }\end{array}$ & EAGI-adjusted & $\begin{array}{l}25 \% \text { improvement in rural areas; } 50 \% \\
\text { improvement in urban areas }\end{array}$ \\
\hline $\begin{array}{l}\text { Substantial } \\
\text { improvement in } \\
\text { EAGI }\end{array}$ & EAGI-adjusted & $\begin{array}{l}75 \% \text { improvement in urban areas; } 50 \% \\
\text { improvement in rural areas }\end{array}$ \\
\hline
\end{tabular}

The high-resolution consumption data gives a good indication of current electricity access and consumption levels in SSA and is used to calibrate the model.

Table 3 summarizes the scenarios considered in the electrification analysis. We implement a baseline scenario based on the original TIMER regional consumer discount rates that only consider household income inequality as discussed in Daioglou et al. (2012). We then run the model implementing our novel EAGI-adjusted discount rate scenario, with country-level urban/rural heterogeneous discount rates. We also test two scenarios simulating the improvement of the EAGI index (as a result of e.g. regulatory and market reform) and thus lowering the discount rates. The moderate case assumes $25 \%$ improvement in rural areas

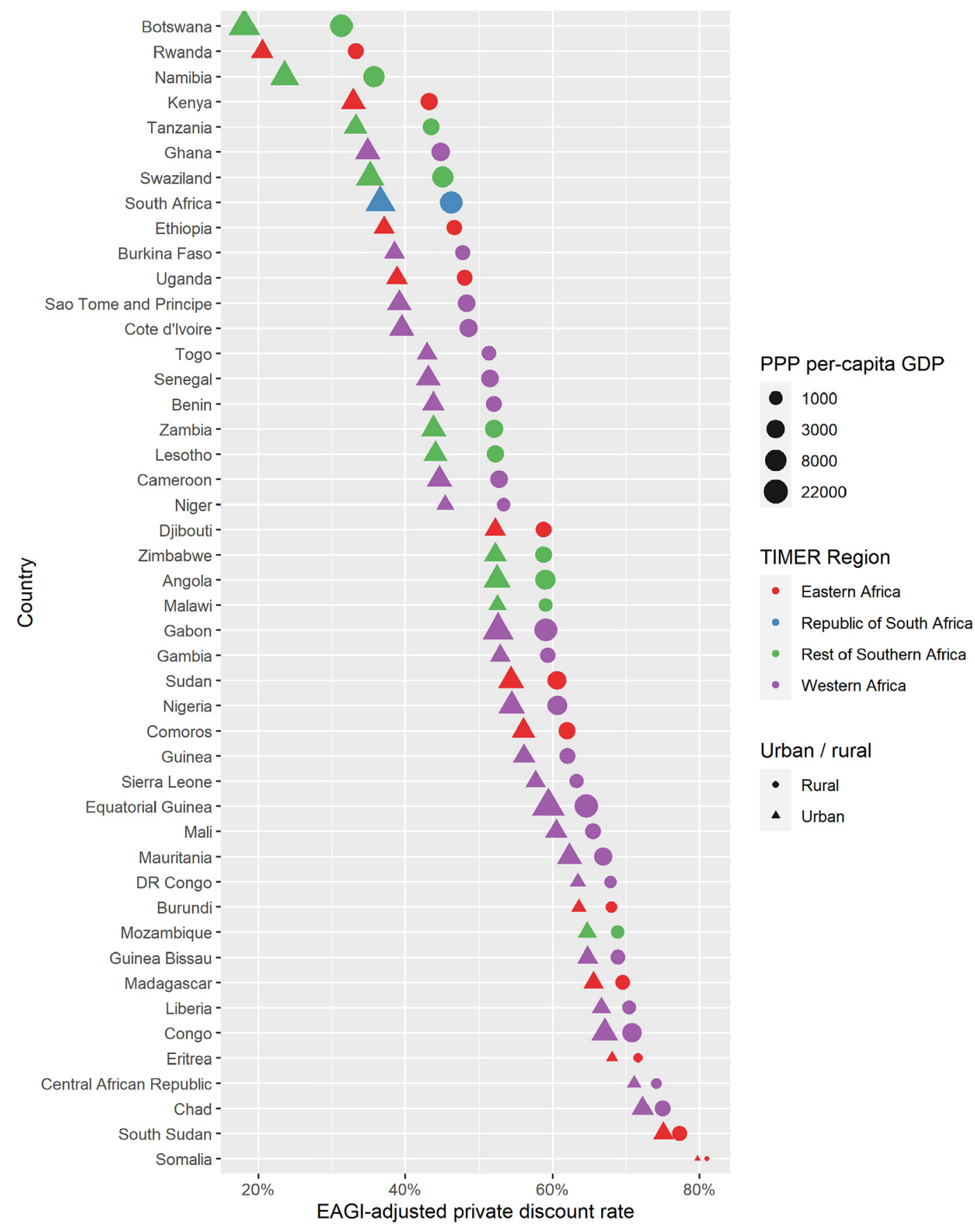

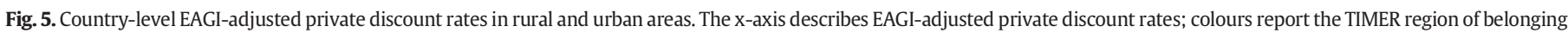
of each country; the symbol size describes PPP per-capita GDP; the shape of the symbol distinguishes between rural and urban areas. 


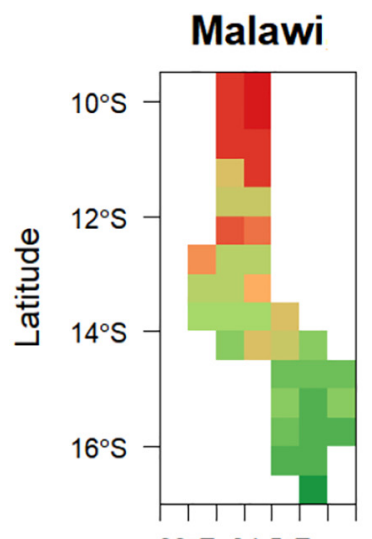

$33^{\circ} \mathrm{E} 34.5^{\circ} \mathrm{E}$

\section{Uganda}

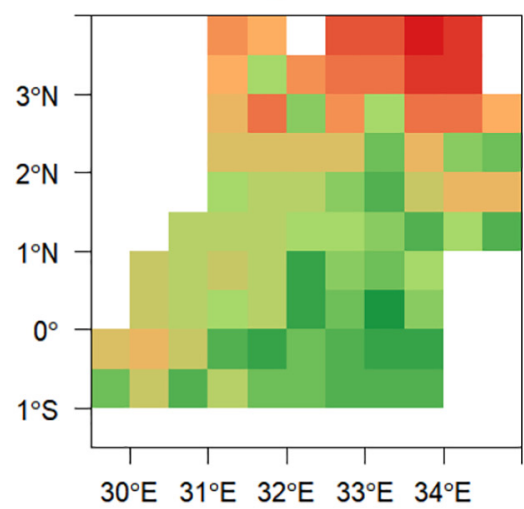

Tanzania

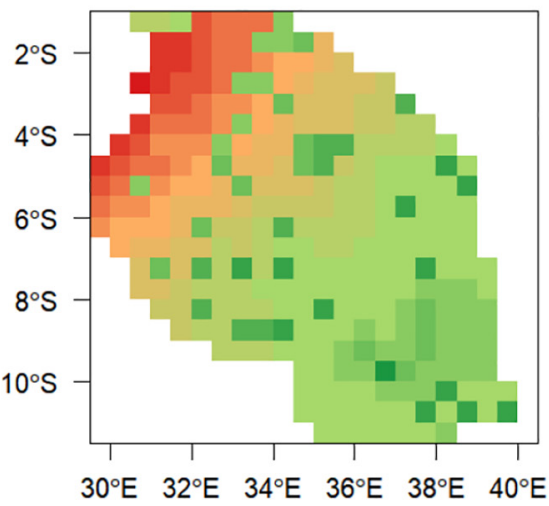

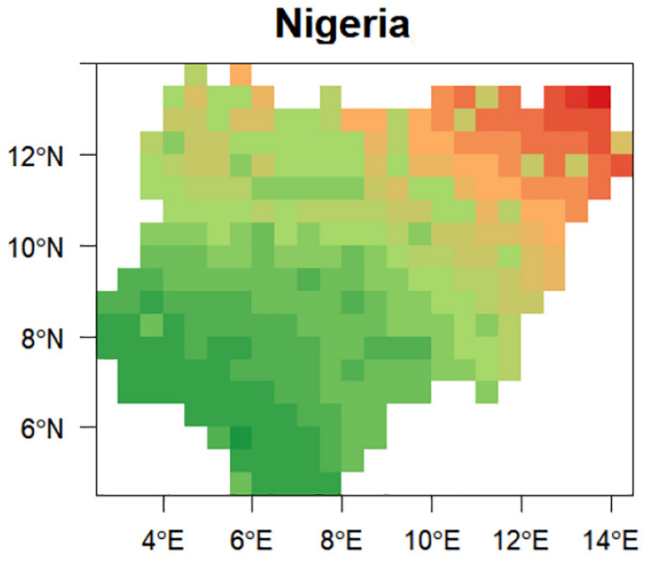

Longitude

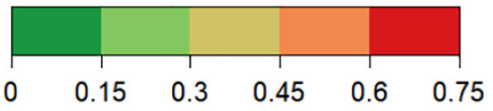

Fig. 6. Sub-national results for the estimated private discount rates (based on the EAGI and adjusted via sub-national covariates) in the selected case-study countries.

and 50\% improvement in urban areas, while the substantial case displays $75 \%$ improvement in urban areas and 50\% improvement in rural areas from the current EAGI values.

\section{Results}

\section{EAGI and implicit discount rates}

Fig. 5 summarizes the calculated EAGI-adjusted discount rates which are considered in the electrification analysis. The underlying numbers are also reported in a tabular form in the Supplementary Materials. The results suggest that there is a significant range of variability across countries, with EAGI-adjusted discount rates of $<20 \%$ in urban areas of Botswana up to rates of $>80 \%$ in rural Somalia. Investing in urban areas is always less risky (i.e. costly) than in rural areas, although the difference decreases as discount rates increase. Among the countries with the lowest EAGI-adjusted discount rates are Botswana, Rwanda, Namibia, Kenya, Tanzania, Ghana, South Africa, and Ethiopia, which all share urban and rural EAGIs lower than $40 \%$ and $50 \%$, respectively. Not by chance, according to the recent national statistics reported in IEA and IRENA (2020), these countries are among those with the steepest growth in electrification levels since 2010. Conversely, the risk premium is deemed very high in Somalia, South Sudan, Chad, the Central African Republic, Eritrea or the Republic of the Congo.
As expected, most of these countries have some of the lowest-ranking figures for both electricity access levels and their growth rates. Yet, notable exceptions exist, such as for the case of the Republic of the Congo, where a risky profile driven by poor performance in the energy access regulation and corruption indicators has not prevented the country from experiencing a significant growth in electricity access. This shows that there is not necessarily a linear relationship between private discount rates and electricity access progress. One reason for this is that public investment in infrastructure is sometimes not well balanced into market mechanisms and can be driven by political objectives rather than market considerations. This is mostly the case for public-owned and controlled infrastructure, such as expansion of the national grid. Conversely, the market for off-grid electrification is dominated by private players which are more responsive to economic considerations. Our paper is mainly looking at the latter players, namely at the challenges faced by private players in their electricity access investment decisions.

A systematic validation of the estimates private discount rates is unfeasible because of the lack of public data about discount rates used by IPPs in real projects (especially small-scale projects like mini-grids) in different countries of sub-Saharan Africa. The limited evidence available relates only to renewable energy, utility-scale projects in the most welldeveloped markets of SSA (Pueyo et al., 2016; Thornton, 2018). These studies report costs of equity of $18 \%$ in Kenya and $27 \%$ in Ghana, which are both not far from our estimates for urban areas in these countries reported in Fig. 5. 
As detailed in Fig. 6, we fine-tune our methodology in four selected case-study countries where we consider sub-national heterogeneity in the EAGI-adjusted discount rates. The results provide a more detailed layer of information on how the potential sources of risk for investors are located within a country. Not only the maps make the urban-rural divide evident, but also, they put considerable weight on remoteness, poverty, and the historical conflict record and ethnical exclusion.

\section{Optimal technology mix and investment requirements}

Fig. 7 presents the results of the electrification analysis in terms of the optimal share of electrification systems among households in 2030. As discussed in Input data and scenarios considered, it compares two main scenarios: a baseline (calibrated on historical electrification progress and investment) and a universal electricity access variant (imposing universal electricity access by 2030). Each scenario is simulated both with a default discount rate configuration (regional $D R$ ) and with country-specific, urban-rural heterogeneous DRs (EAGI-adjusted DR).

The results show that in the baseline scenario standalone energy access systems (e.g. diesel gen-sets and solar home systems) display a comparatively higher penetration relative to the central grid extension when running an analysis based on EAGI-adjusted DRs. This is because the baseline scenario implies the persistence of electricity access gaps in 2030 precisely in areas with high discount rates (where historically electricity access progress has lagged behind). Conversely, areas gaining electricity access are likely to display better governance performance and therefore are more attractive for private developers of decentralised systems, resulting in a switch from central grid access to standalone system access. The more detailed spatial distribution of risk increases the proportion of sites that can be successfully electrified by private energy access solutions providers.

In the universal electricity access scenario (where - by design - even areas with poor governance receive electricity access), the heterogeneity in the characterisation of risk through the EAGI-adjusted DRs emerges as a relative aversion to standalone and mini-grid systems. The main reason behind this finding is that in general, these energy access solutions (and in particular solar PV-based decentralised systems) have a higher per new connection CAPEX to OPEX ratio (capital upfront costs to operational costs, i.e. fuels, maintenance...) relative to the national grid. Thus, a higher discount rate (i.e. a higher cost of capital) tends to favour systems with comparatively lower CAPEX to OPEX ratios (and therefore LCOEs), as lending capital today is expensive and future

\section{Optimal electrification set-up}

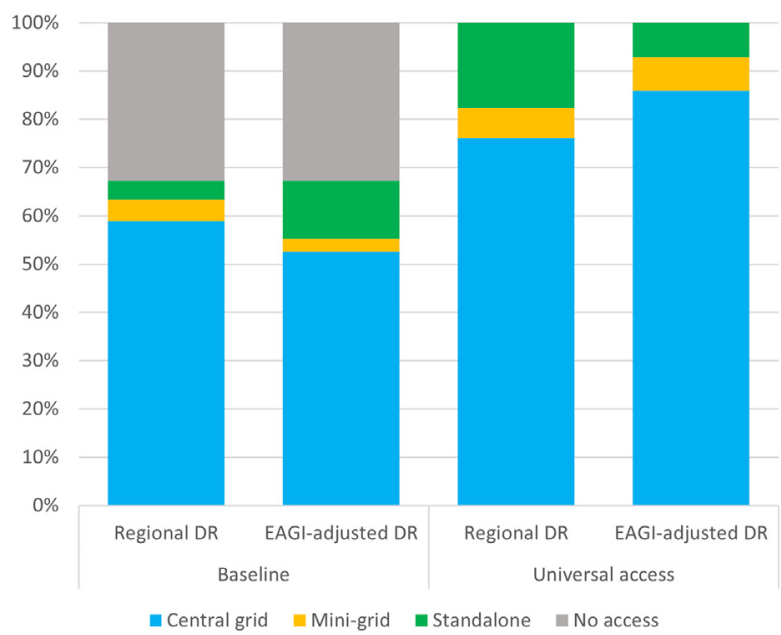

Fig. 7. Results over the optimal technology mix in baseline and EAGI-adjusted scenarios.

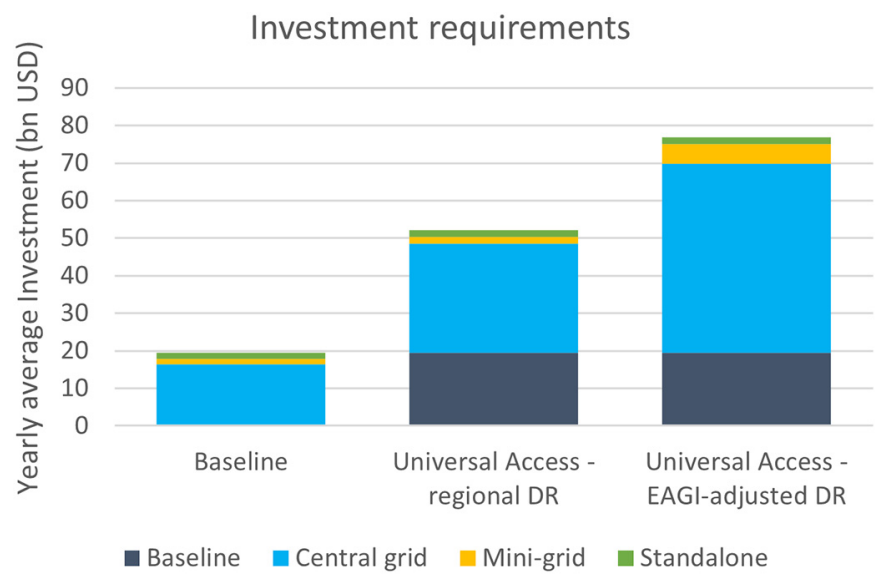

Fig. 8. Results over the electrification investment requirements in baseline and EAGIadjusted scenarios.

costs are more heavily discounted. Coincidentally, areas with the largest energy access deficit (i.e. which remain without electricity access in the baseline variant) are likely areas with poorer performance of the EAGI index. Thus, a more detailed characterisation of risk sheds light on the intrinsic difficulty of decentralised systems to have a substantial role under a risky environment for private investors. In fact, in high risk countries, model results suggesting access through the central grid do not guarantee access will be achieved. They just show that the private sector is reluctant to invest in decentralised systems leaving the central grid as the least expensive solution to expanding access.

Fig. 8 reports the results of the same scenarios in terms of the system-specific yearly average investment requirements. The annual investment gap under standard DR characterisation is $~ 30 \mathrm{bn}$, which is indeed similar to Dagnachew et al. (2017). Applying the EAGIadjusted discount rates leads to an additional investment gap of 25 bn/year. This is the result of different trends: on the one hand, investment in all access systems becomes ceteris paribus more costly. In addition, the technological shift observed in Fig. 7 - namely the crowding out from decentralised systems - implies the need to expand the central grid even in areas where it is very costly to do so (because of remoteness, low demand density, and risk encapsulated in the EAGI).

\section{Simulating improvements in the EAGI}

To evaluate the sensitivity of the results, we explore the significance of improvements in the EAGI index as a result of political and economic reform. The moderate case assumes $25 \%$ improvement in rural areas (R) and 50\% improvement in urban areas (U), while the substantial case displays 75\% improvement in urban areas and 50\% improvement in rural areas from the current EAGI values.

Figs. 9A-B show the results for respectively the share of new connections and the investment requirements. As expected, gradually increasing regulatory quality leads to growing shares of decentralised (and mainly standalone) systems and lower investment requirements, due to both structural capital cost reduction and to CAPEX/OPEX ratio variations which in turn reshape the optimal energy access technology setup. Yet, mini-grids and standalone systems remain limited in terms of the number of new connections. Even in the substantial EAGI improvement case, their penetration is altogether $<20 \%$.

\section{Results summary}

Together, the results from the TIMER model suggest that the uptake of decentralised systems for achieving universal energy access requires governance reform to lower the discount rate. In the lack of such 
A

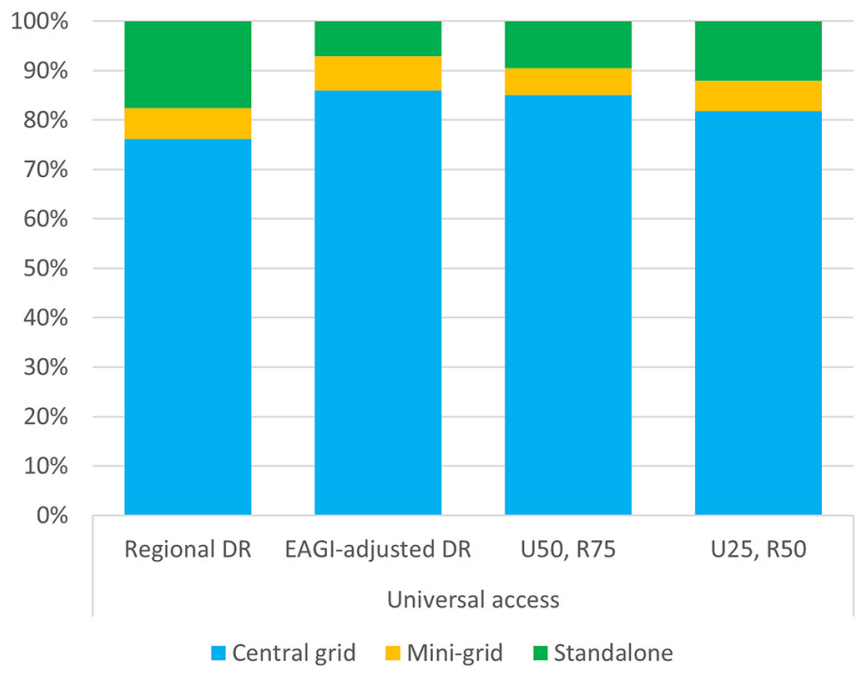

B

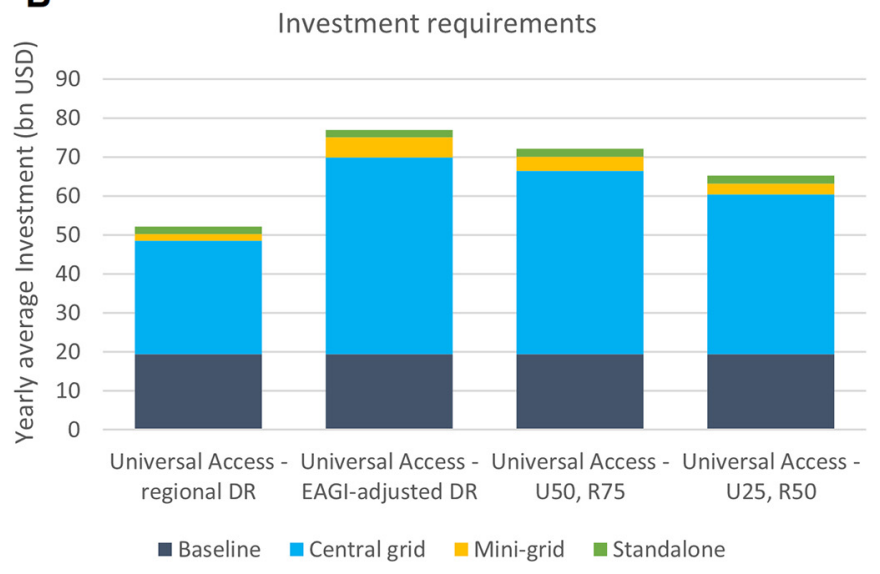

Fig. 9. Results of the sensitivity analysis across scenarios. (A) Sensitivity of the optimal electrification technology set-up by the share of new connections; (B) Sensitivity of the electrification investment requirements, by electrification technology.

institutional transformations, the key risk incurred by countries with electrification deficit is that areas which would be cost-optimally served by decentralised systems such as mini-grids and standalone systems do not get technologies installed because of the high DRs pushing away private investors. At the same time, the government would likely face financial barriers in connecting those areas to the national grid because of their distance to the existing grid or the low local demand which would not allow recouping the investment.

In addition, the results presented in this section are likely to vary with the consideration of different demand targets and technologyspecific cost variation. Yet, these additional sensitivity runs are beyond the scope of this paper. The results show that varying perceived risk have a ceteris paribus significance for electricity access planning. The most prominent effect is on the total investment requirements, but a significant effect is also observed in the optimal technology mix.

\section{Discussion}

\section{Policy implications}

Recent literature based on stakeholder interviews and institutional analysis (Dagnachew et al., 2020; Simone \& Bazilian, 2019) has discussed how energy resource abundance is not a sufficient criterion to ensure elimination of energy poverty because of the existence of a variety of barriers. These barriers include market failures (e.g. due to a bundled, highly centralised energy sector) such as a lack of competition and high transaction costs; market distortions such as regressive subsidies hampering investment decisions; economic and financial barriers driven by risk perceptions for private system developers as a result of a multitude of causes (political, regulatory, monetary, conflict risks).

Building on this qualitative understanding of the main challenges to universal electrification in SSA, our paper has developed and implemented a methodology to quantitatively and explicitly account for the role of regulatory, political, and market risk factors in electricity access modelling. This analysis led us to a key finding: the results of the electricity supply analysis change substantially compared to a pure, conventional techno-economic assessment. Namely, accounting for different risk factors crowds out investment in decentralised systems which - compared to a conventional analysis - shrink their share on new connections when pursuing a universal electricity access policy. This contraction is the result of risks increasing private discount rates, and therefore the willingness of private actors to invest in decentralised energy access systems (which have higher CAPEX-to-OPEX ratios).

With regards to the interpretation of the modelling exercise results, it is important to note that the universal electrification scenarios quantify the technological and investment requirements to achieve SDG 7.1.1 under a set of given conditions - including the current risk -, but it does not provide any specific evidence that those outcomes identified as optimal will actually materialize. What does this mean? For instance, the significant growth in the share of connections via central grid expansion in the EAGI-adjusted DRs variants (and therefore the growth in the overall investment requirements) casts doubts on the actual possibility of deploying large-scale public infrastructure with considerable governmental expenditure to reach sparse communities with low demand loads. These findings are in agreement with the results from the stakeholder interviews of Dagnachew et al. (2020), who claim that 'achieving universal access to electricity through the integration of offgrid systems requires innovative revenue schemes, financial and fiscal incentives and elimination of market distortions'.

How can these barriers be overcome, and decentralised systems realise the potential that they are claimed to have (IEA, 2019; Dagnachew et al., 2017)? The keyword here is reform. Reform of the regulation of the energy sector to enable a competitive and attractive environment for private and foreign investors; reform of the bureaucracy mechanisms to ensure accountability, efficacy and the reduction of corruption and clientelism among decision makers; market reform, to ensure the reduction of frictions in the labour and capital markets; fiscal reform, to ensure tariffs (including energy taxation) are progressive and development investments, such as energy access, meet favourable conditions; monetary policy aimed at ensuring the minimisation of exchange rate fluctuations which might otherwise lead to fast appreciation or depreciation of the currency, with potential losses for foreign investors. Regulatory reform is not solely a task for governments in SSA, as policies implemented in countries of the Global North (where most donors and investors are based) also have a relevant weight. For instance, competitive subsidies such as results-based financing from developed economies can support private companies in SSA to invest.

In the meantime, private companies in the energy access sector are seeking strategies to minimise their operational risk and maximise value to be able to invest in new infrastructure even when facing relatively high discount rates. Pay-as-you-go (PAYG) schemes among communities served by decentralised energy access solutions are gaining growing relevance, in particular when combined with 'over the counter' electrification products such as plug-and-play solar kits and solar home 
systems. From the companies' perspective, these innovative models can be seen as a hedging investment. PAYG business models in fact allow companies to set high interest rates - and thus make profit from quasi microfinancing investments - while at the same time lifting poor communities from the burden of simply unsustainable high upfront costs such as national grid connection charges or standalone systems purchase.

While central grid infrastructure investment has also recently received the attention of large-scale foreign (in most cases Chinese, e.g. GEIDCO) corporations in the context of pan-sectoral market development operations such as the prospect of a global grid, these developments are likely to be strongly biased towards certain regions and neglect others, because they are not driven by explicit energy access objectives. Contrarily, these CAPEX-intensive investments target large demand hotspots such as industrial areas or metropolitan cities because they have the specific objective of ensuring the grid natural monopoly and then be able to import power from abroad.

\section{Limitations}

Our study is a first-order attempt to encapsulate regulatory, social, and other factors in the conventional techno-economic leastcost analysis of energy access. Yet, it must be remarked that the assumptions made in this application of the model inevitably result in simplifications. The main limitations include (i) the dataavailability dependent selection of the factors included in the EAGI; (ii) the simple mechanism linking the EAGI to the discount rates; (iii) the intrinsic limitations of the TIMER electrification model, detailed in Dagnachew et al. (2017). Only part of the impact of regulatory, social, and other factors is captured by the EAGI index and the discount rate, and thus in the modelling. For instance, the approach is not capable of accounting for social acceptability of certain technologies. Moreover, the methodology estimates country-level private discount rates of the decentralised energy access sector as a whole, without differentiating between different technologies. Furthermore, the data from Reddy (1996), which links income levels with private energy investment discount rates, is calibrated on India. GDP per capita levels are very similar between the data used by Reddy and current rural SSA, but different contexts may influence the relation. Further research should investigate the possibility of recalibrating the approach, using recent information on energy carrier choice and investment. This could exploit e.g. the World Bank Multi-Tier Framework surveys carried out over recent years in different sub-Saharan African countries.

Another crucial limitation where further investigation is important regards the validation of the estimated discount rates against discount rates considered by IPP projects in SSA. However, given the lack of public data on these type of investments in the region, a comparative assessment is not feasible at this stage. A related point is that the estimated country-level private discount rates are applied to all the players in the decentralised energy access sector in the TIMER model. In reality, households and companies each consider different discount rates in their energy investments. This concern is partly mitigated by the fact that households often finance their energy investment with microcredit, which allows them to access capital at lending rates much closer to those accessed by companies than they would independently be able to. Finally, the lack of validation data for the estimated discount rates makes it simply too much uncertain to differentiate between these different groups. The discount rates proxy estimation introduced in this paper is indeed motivated by the lack of such data. Data collection and disclosure initiatives on energy access investment would strongly benefit energy access planners. A further important aspect regards the lack of consideration of investors peering dynamics - found to be important in the literature on investment in developing countries and yet challenging to implement due to the lack of granular historical data on investment flows in the energy access sector.
Future research should aim at tackling these key limitations to evaluate the robustness of our results over the sensitivity of electrification investment to different sources of investment risk.

\section{Conclusions}

We have shown that regulatory quality and governance can have a significant impact on the optimal investment strategy for private players involved in energy access infrastructure in developing countries. Our results are directly relevant to policymakers, because they show that targeting specific domestic issues by means of better governance and regulation can increase incentives to attract more private-sector investment. This could diminish the investment requirements from the central government, e.g. to expand the central grid.

With poor regulation, markets, and governance, it is likely that the expansion of the national grid is the only way to bring electricity to communities that are currently without access, because decentralised systems developers do not have the sufficient economic incentive to develop decentralised energy access systems and households face high lending rates. In the model, this is reflected by the fact that operational costs become less relevant and capital costs more relevant for energy investment decisions with higher discount rates. Investors therefore tend to prefer systems with lower capital costs to operational costs ratios. Since decentralised systems have comparatively higher upfront costs per new electricity connection than extending the central grid, their development becomes less and less attractive under higher discount rates. In turn, under poor regulatory quality and therefore energy sector governance, the government is itself also less likely to invest in the grid, locking the country into an energy poverty trap and reinforcing electricity access inequality (Falchetta \& Pachauri, 2020).

We recommend future research assessing electrification to give more prominent role to governance, regulation, and risk dynamics. Assessing what is the least-cost technology is not enough to have this installed if there are no market conditions to attract players that can actually put the infrastructure into place on a large scale. This is crucial to achieve SDG 7.1.1 timely.

\section{Declaration of competing interest}

The authors declare no competing interests.

\section{Acknowledgements}

The first author gratefully acknowledges financial support from Fondazione Eni Enrico Mattei and the Italian Ministry of University and Research. The second and third authors acknowledge funding from the Dutch Ministry of Foreign Affairs, the Netherlands, through its Directorate-General of Trade and International Cooperation. The fourth author was partially supported by the CIEP. The authors would like to thank Prof. Gert Jan Kramer.

\section{Data availability}

The R code for replicating the EAGI index calculation will be hosted at a public Github repository. A Zenodo repository will host the input data and the raw results of the energy model.

\section{References}

Afidegnon, K. (2019). Success factors for power project development businesses in SubSaharan Africa, Walden Dissertations and Doctoral Studies. https://scholarworks.wa ldenu.edu/dissertations/6502.

Asongu, S., \& Nwachukwu, J. (2015). Drivers of FDI in fast growing developing countries: Evidence from bundling and unbundling governance, African Governance and Development Institute Working Paper.

Bandalos, D. L., \& Boehm-Kaufman, M. R. (2009). Four common misconceptions in exploratory factor analysis, statistical and methodological myths and urban legends: Doctrine. verity and fable in the organizational and social sciences., 2009, 61-87. 
Blimpo, M. P., Postepska, A., \& Xu, Y. (2020). Why is household electricity uptake low in Sub-Saharan Africa? World Development., 133, 105002. https://doi.org/10.1016/j. worlddev.2020.105002.

Bonan, J., Pareglio, S., \& Tavoni, M. (2017). Access to modern energy: A review of barriers, drivers and impacts. Environment and Development Economics., 22, 491-516.

Booysen, F. (2002). An overview and evaluation of composite indices of development. Social Indicators Research, 115-151.

M.B. Cahill, N. Sanchez, Using principal components to produce an economic and social development index: An application to Latin America and the U.S, AEJ. 29 (2001) 311-329.

Chen, S., \& Ma, H. (2017). Peer effects in decision-making: Evidence from corporate investment. China Journal of Accounting Research., 10, 167-188. https://doi.org/10. 1016/j.cjar.2016.11.002

Dagnachew, A. G., Hof, A. F., Roelfsema, M. R., \& van Vuuren, D. P. (2020). Actors and governance in the transition toward universal electricity access in Sub-Saharan Africa. Energy Policy, 143, 111572.

Dagnachew, A. G., Lucas, P. L., Hof, A. F., Gernaat, D. E. H. J., de Boer, H. -S., \& van Vuuren, D. P. (2017). The role of decentralized systems in providing universal electricity access in Sub-Saharan Africa - A model-based approach. Energy., 139, 184-195. https:// doi.org/10.1016/j.energy.2017.07.144.

Dagnachew, A. G., Lucas, P. L., Hof, A. F., \& van Vuuren, D. P. (2018). Trade-offs and synergies between universal electricity access and climate change mitigation in Sub-Saharan Africa. Energy Policy, 114, 355-366. https://doi.org/10.1016/j. enpol.2017.12.023.

Daioglou, V., van Ruijven, B. J., \& van Vuuren, D. P. (2012). Model projections for household energy use in developing countries. Energy., 37, 601-615. https://doi.org/10. 1016/j.energy.2011.10.044.

Davis, B., Di Giuseppe, S., \& Zezza, A. (2017). Are African households (not) leaving agriculture? Patterns of households' income sources in rural Sub-Saharan Africa. Food Policy, 67, 153-174. https://doi.org/10.1016/j.foodpol.2016.09.018.

De Luca, G., Hodler, R., Raschky, P. A., \& Valsecchi, M. (2018). Ethnic favoritism: an axiom of politics? Journal of Development Economics., 132, 115-129. https://doi.org/10.1016/ j.jdeveco.2017.12.006

De Vries, B., Van Vuuren, D., Den Elzen, M., \& Janssen, M. (2002). Targets IMage Energy Regional (TIMER) Model Technical Documentation .

Dittrich Hallberg, J. (2012). PRIO conflict site 1989-2008: A geo-referenced dataset on armed conflict. Conflict Management and Peace Science., 29, 219-232. https://doi. org/10.1177/0738894211433168.

Drogendijk, R., \& Blomkvist, K. (2013). Drivers and motives for Chinese outward foreign direct investments in Africa. Journal of African Business., 14, 75-84

Eberhard, A., \& Gratwick, K. (2013). Investment power in Africa: where from and where to. Geo. J. Int'l Aff., 14, 39.

Eberhard, A., Gratwick, K., Morella, E., \& Antmann, P. (2016). Independent power projects in Sub-Saharan Africa: Lessons from five key countries The World Bank.

Eberhard, A., Gratwick, K., Morella, E., \& Antmann, P. (2017). Accelerating investments in power in sub-Saharan Africa. Nature Energy., 2, 17005.

Eifert, B., Gelb, A., \& Ramachandran, V. (2005). Business environment and comparative advantage in Africa: Evidence from the investment climate data. Banque Mondiale, Washington: DC., 195-233.

D. Douglas A. Ellman, The reference electrification model: A computer model for planning rural electricity access, Thesis, Massachusetts Institute of Technology, 2015. http:// dspace.mit.edu/handle/1721.1/98551 (accessed September 25, 2018).

J.J. Emery, Governance and private investment in Africa, in: Beyond structural adjustment the institutional context of African development, Springer, 2003: pp. 241-261.

Enerdata, Study of the cost of electricity projects in Africa for the African Development Bank, (2016).

ESMAP (2019). Mini grids for half a billion people. https://openknowledge.worldbank. org/handle/10986/31926(Accessed 6 February 2020).

Falchetta, G., \& Pachauri, S. (2020). Byers, Edward. Olha, Parkinson, SImon, Satellite observations reveal inequalities in the progress and effectiveness of recent electrification in sub-Saharan Africa, One Earth: Danylo.

Falchetta, G., Pachauri, S., Parkinson, S., \& Byers, E. (2019). A high-resolution gridded dataset to assess electrification in sub-Saharan Africa. Scientific Data., 6, 1-9. https:// doi.org/10.1038/s41597-019-0122-6.

Gregory, J., \& Sovacool, B. K. (2019). The financial risks and barriers to electricity infrastructure in Kenya, Tanzania, and Mozambique: A critical and systematic review of the academic literature. Energy Policy, 125, 145-153.

Hair, J. F. (2009). Multivariate data analysis.

Hermes, E. (2017). Euler Hermes country risk ratings September.

Hirshleifer, J. (1961). Risk, the discount rate, and investment decisions. The American Economic Review., 51, 112-120.

Hornberger, K., Battat, J., \& Kusek, P. (2011). Attractive FDI: How much does investment climate matter?

Ibrahim, M. (2013). Ibrahim index of African governance, The Mo Ibrahim Foundation.

IEA, Africa energy outlook 2019, (2019). https://webstore.iea.org/africa-energy-outlook2019.

IEA, \& IRENA (2020). United Nations Statistics Division, tracking SDG7: The energy progress report 2020.

Investing com, African government bonds yields, Investing com (2020). https://www. investing.com/rates-bonds/african-government-bonds (accessed January 27, 2020).

Iyer, G. C., Clarke, L. E., Edmonds, J. A., Flannery, B. P., Hultman, N. E., Mcjeon, H. C., \& Victor, D. G. (2015). Improved representation of investment decisions in assessments of CO 2 mitigation. Nature Climate Change., 5, 436-440.

Jensen, N. M. (2003). Democratic governance and multinational corporations: Political regimes and inflows of foreign direct investment. International Organization., 57, 587-616. https://doi.org/10.1017/S0020818303573040.
R. Karhammar, A. Sanghvi, E. Fernstrom, M. Aissa, J. Arthur, J. Tulloch, I. Davies, S. Bergman, S. Mathur, Sub-saharan africa: Introducing low-cost methods in electricity distribution networks, Energy Sector Management Assistance Program (ESMAP), Tech. Rep. 104 (2006).

Kaufmann, D., Kraay, A., \& Mastruzzi, M. (2011). The worldwide governance indicators: methodology and analytical issues. Hague Journal on the Rule of Law., 3, 220-246.

Khatun, T. (2009). Measuring environmental degradation by using principal component analysis, Environment. Development and Sustainability., 11, 439-457. https://doi.org/ 10.1007/s10668-007-9123-2.

Khennas, S. (2012). Understanding the political economy and key drivers of energy access in addressing national energy access priorities and policies: African perspective. Energy Policy, 47, 21-26. https://doi.org/10.1016/j.enpol.2012.04.003.

Korkovelos, A., Mentis, D., Bazilian, M., Howells, M., Saraj, A., Hotaki, S. F., \& MissfeldtRingius, F. (2020). Supporting electrification policy in fragile states: A conflict-adjusted geospatial least cost approach for Afghanistan. Sustainability., 12, 777. https://doi.org/10.3390/su12030777.

Lai, D. (2003). Principal component analysis on human development indicators of China. Social Indicators Research, 319-330.

Lintner, J. (1969). The valuation of risk assets and the selection of risky investments in stock portfolios and capital budgets: A reply. The Review of Economics and Statistics., 51, 222-224. https://doi.org/10.2307/1926735.

P.L. Lucas, A.G. Dagnachew, A.F. Hof, Towards universal electricity access in Sub-Saharan Africa, (2017). https://www.pbl.nl/en/publications/towards-universal-electricity-a ccess-in-sub-saharan-africa (accessed January 21, 2020).

McCollum, D. L., Zhou, W., Bertram, C., De Boer, V., Bosetti, S., Busch, J., Després, L., Drouet J. Emmerling, Fay, M., et al. (2018). Energy investment needs for fulfilling the Paris Agreement and achieving the Sustainable Development Goals. Nature Energy, 3, 589.

Mentis, D. Howells, M., Rogner, H., Korkovelos, A., Arderne, C., Zepeda, Eduardo, Siyal, S. Taliotis, C., Bazilian, M., A. de Roo, Tanvez, Y., Oudalov, Alexandre, \& Scholtz, E. (2017). Lighting the World: the first application of an open source, spatial electrification tool (OnSSET) on Sub-Saharan Africa. Environ. Res. Lett., 12, Article 085003.

Moner-Girona, M., Bódis, K., Morrissey, J., Kougias, I., Hankins, M., Huld, T., \& Szabó, S (2019). Decentralized rural electrification in Kenya: Speeding up universal energy access. Energy for Sustainable Development., 52, 128-146. https://doi.org/10.1016/j.esd. 2019.07.009.

Morrissey, J. (2019). Achieving universal electricity access at the lowest cost: A comparison of published model results. Energy for Sustainable Development., 53, 81-96. https://doi.org/10.1016/j.esd.2019.09.005.

Ndikumana, L., \& Verick, S. (2008). The linkages between FDI and domestic investment: Unravelling the developmental impact of foreign investment in Sub-Saharan Africa. Development Policy Review., 26, 713-726.

Nerini, F. F., Broad, O., Mentis, D., Welsch, M., Bazilian, M., \& Howells, M. (2016). A cost comparison of technology approaches for improving access to electricity services. Energy., 95, 255-265. https://doi.org/10.1016/j.energy.2015.11.068.

Orea, L., Growitsch, C., \& Jamasb, T. (2015). Using supervised environmental composites in production and efficiency analyses: An application to Norwegian electricity networks. Competition and Regulation in Network Industries., 16, 260-287. https://doi. org/10.1177/178359171501600303.

Patankar, N., de Queiroz, A. R., DeCarolis, J. F., Bazilian, M. D., \& Chattopadhyay, D. (2019). Building conflict uncertainty into electricity planning: A South Sudan case study. Energy for Sustainable Development., 49, 53-64. https://doi.org/10. 1016/j.esd.2019.01.003.

Pesaresi, M., \& Freire, S. (2016). GHS settlement grid following the REGIO Model 2014 in application to GHSL Landsat and CIESIN GPW v4-Multitemporal (1975-1990-2000-2015). Joint Research Centre, JRC Data Catalogue: European Commission.

Powanga, L., \& Giner-Reichl, I. (2019). China's contribution to the African power sector: Policy implications for African countries, Journal of Energy. https://doi.org/10.1155/ 2019/7013594.

Pueyo, A., Bawakyillenuo, S., \& Osiolo, H. (2016). Cost and returns of renewable energy in Sub-Saharan Africa: A comparison of Kenya and Ghana IDS .

PWC, Africa: A closer look at value, 2015.

Ram, R. (1982). Composite indices of physical quality of life, basic needs fulfilment, and income: A "principal component"representation. Journal of Development Economics., $11,227-247$

Ramachandran, V., Gelb, A. H., \& Shah, M. K. (2009). Africa's private sector: What's wrong with the business environment and what to do about it. CGD Books.

Reddy, B. S. (1996). Consumer discount rates and energy carrier choices in urban households. International Journal of Energy Research., 20, 187-195.

K. Riahi, D.P. van Vuuren, E. Kriegler, J. Edmonds, B.C. O'Neill, S. Fujimori, N. Bauer, K. Calvin, R. Dellink, O. Fricko, W. Lutz, A. Popp, J.C. Cuaresma, S. KC, M. Leimbach, L. Jiang, T. Kram, S. Rao, J. Emmerling, K. Ebi, T. Hasegawa, P. Havlik, F. Humpenöder, L.A. Da Silva, S. Smith, E. Stehfest, V. Bosetti, J. Eom, D. Gernaat, T. Masui, J. Rogelj, J. Strefler, L. Drouet, V. Krey, G. Luderer, M. Harmsen, K. Takahashi, L. Baumstark, J.C. Doelman, M. Kainuma, Z. Klimont, G. Marangoni, H. Lotze-Campen, M. Obersteiner, A. Tabeau, M. Tavoni, The shared socioeconomic pathways and their energy, land use, and greenhouse gas emissions implications: An overview, Global Environmental Change. 42 (2017) 153-168. https://doi.org/10.1016/J.GLOENVCHA.2016.05.009.

RISE (2019). RISE Renewable indicators for sustainable energy. http://rise.esmap.org/.

Ritchie, R., \& Mispy, O. -O. (2018). Measuring progress towards the sustainable development goals, SDG-Tracker. Website: Org.

P.A. Ryan, T.J. Gallagher, Implied risk adjusted discount rates, Academy of Business Education, Savannah, GA [Online] https://docs.wixstatic.com/Ugd/4ccb80_ c318f274d56c4f9c8840610e28107922.pdf (Accessed 31 July 2017). (2006).

Schleich, J., Gassmann, X., Faure, C., \& Meissner, T. (2016). Making the implicit explicit: A look inside the implicit discount rate. Energy Policy, 97, 321-331. https://doi.org/10. 1016/j.enpol.2016.07.044. 
Schmidt, T. S. (2019). Making electrification models more realistic by incorporating differences in institutional quality and financing cost. Prog. Energy., 2, Article 013001. https://doi.org/10.1088/2516-1083/ab43a3.

Sergi, B., Babcock, M., Williams, N. J., Thornburg, J., Loew, A., \& Ciez, R. E. (2018). Institutional influence on power sector investments: A case study of on-and off-grid energy in Kenya and Tanzania. Energy Research E Social Science., 41, 59-70.

Short, W., Packey, D. J., \& Holt, T. (1995). A manual for the economic evaluation of energy efficiency and renewable energy technologies. https://doi.org/10.2172/35391.

Simone, T., \& Bazilian, M. (2019). The role of international institutions in fostering sub-Saharan Africa's electrification. The Electricity Journal., 32, 13-20.

Spyrou, E., Hobbs, B. F., Bazilian, M. D., \& Chattopadhyay, D. (2019). Planning power systems in fragile and conflict-affected states. Nature Energy., 4, 300-310. https://doi.org/ 10.1038/s41560-019-0346-x.

E. Stehfest, D. van Vuuren, L. Bouwman, T. Kram, Integrated assessment of global environmental change with IMAGE 3.0: Model description and policy applications, Netherlands Environmental Assessment Agency (PBL), 2014.

Tatem, A. J., Gething, P. W., Bhatt, S., Weiss, D., \& Pezzulo, C. (2013). Pilot high resolution poverty maps. Oxford Uo: Southampton.

Thornton, Grant (2018). Africa renewable energy discount rate survey - 2018. https:// www.grantthornton.co.uk/globalassets/1.-member-firms/united-kingdom/pdf/ documents/africa-renewable-energy-discount-rate-survey-2018.pdf.
Train, K. (1985). Discount rates in consumers' energy-related decisions: a review of the literature. Energy (Oxford)., 10, 1243-1253.

Transparency International, Corruption Perceptions Index 2018: Score timeseries since 2012, 2019.

Van Ruijven, B., Urban, F., Benders, R. M., Moll, H. C., Van Der Sluijs, J. P., De Vries, B., \& Van Vuuren, D. P. (2008). Modeling energy and development: An evaluation of models and concepts. World Development., 36, 2801-2821.

van Ruijven, B. J., Schers, J., \& van Vuuren, D. P. (2012). Model-based scenarios for rural electrification in developing countries. Energy., 38, 386-397. https://doi.org/10. 1016/j.energy.2011.11.037.

Vogt, M., Bormann, N. -C., Rüegger, S., Cederman, L. -E., Hunziker, P., \& Girardin, L. (2015) Integrating data on ethnicity, geography, and conflict: the ethnic power relations data set family. Journal of Conflict Resolution., 59, 1327-1342.

Weiss, D. J., Nelson, A., Gibson, H. S., Temperley, W., Peedell, S., Lieber, A., .. Gething, P. W. (2018). A global map of travel time to cities to assess inequalities in accessibility in 2015. Nature., 553, 333-336. https://doi.org/10.1038/ nature25181.

World Bank (2018). World Bank data. https://data.worldbank.org/(Accessed 20 November 2017). .

I. Zaighum, D.M.Z.A. Karim, Peer effects, financial decisions and industry concentration: SEISENSE Journal of Management. 2 (2019) 13-21. https://doi.org/10.33215/sjom. v2i2.116. 